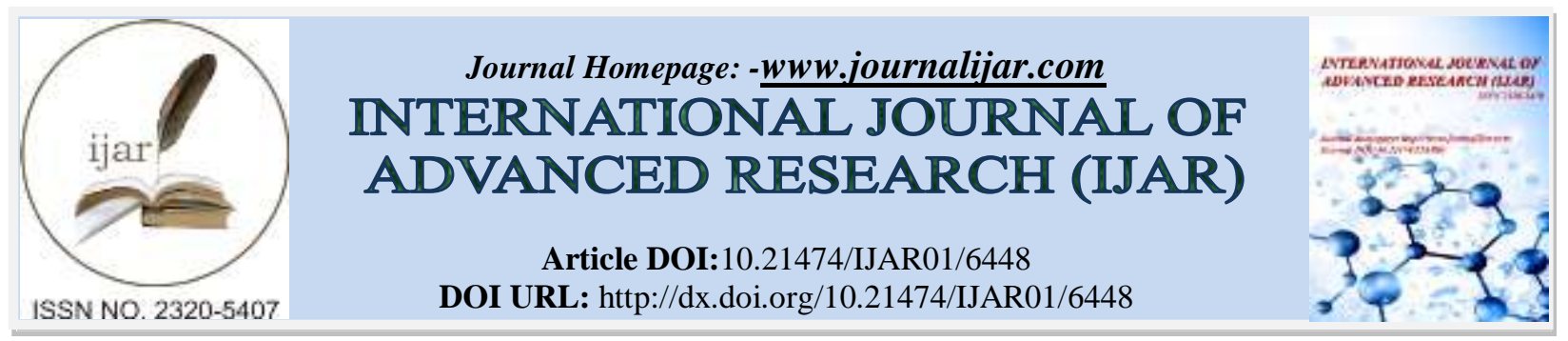

RESEARCH ARTICLE

\title{
EVALUATION OF NOCTURNAL ENURESIS IN THALASSEMIC PATIENTS IN HEREDITARY BLOOD DISEASE CENTER AT KARBALA TEACHING HOSPITAL.
}

\author{
Mohammed Hussein Hamadi Al-Dawwd ${ }^{1}$, Oday Abdul Ridha Mohammed Al Nasari ${ }^{2}$ and Israa Mustafa Salih \\ AL- Musawi ${ }^{3}$. \\ 1. F.I.B.M.S of pediatrics \\ 2. F.I.B.M.S of pediatrics \\ 3. C.A.B.A.P.
}

\section{Manuscript Info}

\section{Manuscript History}

Received: 05 December 2017

Final Accepted: 07 January 2018

Published: February 2018

Keywords:-

Enuresis

Thalassemia

\section{Abstract}

Background: Enuresis in thalasemic patients is one of psychosocial problem that presented to us in hereditary blood disease center at karbala teaching hospital.

Aim: To determine the type of enuresis,gender predominency and associated certain predisposing factors in thalassemia major ,thalassemia intermedia and sickle thalassemic patients in hereditary blood disease center at karbala teaching hospital .

Method: Across sectional study involved sixty-one patients with thalassemia and sickle thalassemia from 396 patients registered in hereditary blood disease center at karbala teaching hospital at age of 5$18 \mathrm{yrs}$ and had enuresis.medical history, physical examination, urinalysis and renal ultrasound were evaluated.

Results: The percentage of primary eneuresis in thalassemic patients were $83.6 \%$.the percentage of male patients were $67.2 \% .75 .4 \%$ had family history of eneuresis .just $13.1 \%$ had urinary tract infection and 98.4\% with normal renal ultrasound.

Conclusion: The percentage of primary to secondary enuresis in thalassemic patient were similar to that of normal populations. The percentage of the males and family history of enuresis in enuretic thalassemic patients were more than that of normal population . After meticulous search we cannot find research concerned with enuretic thalasemic patients in iraq .

Copy Right, IJAR, 2018,. All rights reserved.

\section{Introduction:-}

Nocturnal enuresis refers to the occurrence of involuntary voiding at night after $5 \mathrm{yr}$. [1]

By 5 years of age, 80-85\% are continent at night [2],It maybe primary or secondary; The primary mean nocturnal urinary control never achieved, estimated 75-90\% of children with enuresis). secondary $10-25 \%$. [ 3]. the child was dry at night for at least a few months and then enuresis developed. Inaddition, $75 \%$ of children with enuresis are wet only at night, and $25 \%$ are incontinent day and night. 
About $60 \%$ of children with nocturnal enuresis are boys.Family history is positive in $50 \%$ of cases. Primary nocturnalenuresis may be polygenetic, If one parent was enuretic, each child has a44\% risk of enuresis; if both parents were enuretic, each child has a $77 \%$, Its frequency among adults is <1\%[4]. Hemoglobinopathies abnormalities in 2 pairs of globin chains(tetramer), Over 1000 different mutations of the globin chains of the human hemoglobin molecule have been discovered[5]. Thalassemia refers to a spectrum of diseases characterized by reduced or absent production of one or more globin chains[6].The thalassemias are inherited disorders of hemoglobin $(\mathrm{Hb})$ synthesis. Their clinical severity widely varies, ranging from asymptomatic forms to severe.[7]. Classification of thalassemia:In clinical practice, the most important types affect either $\alpha$ - or $\beta$-chain synthesis. common forms of $\beta$-thalassemia are as follows:

1. Silent carrier $\beta$-thalassemia: Patients are asymptomatic

2. B-Thalassemia trait: Patients have mild anemia

3. Thalassemia intermedia: Patients have anemia of intermediate severity

4. B-thalassemia associated with $\beta$-chain structural variants: The most significant condition in this group of thalassemic syndromes is the $\mathrm{Hb} \mathrm{E} / \beta$ thalassemia

5. Thalassemia major (Cooley anemia): This condition is characterized by transfusion-dependent anemia common forms of $\alpha$-thalassemia are as follows:

1. Silent carrier $\alpha$-thalassemia

2. Thalassemia trait: Characterized by mild anemia

3. $\mathrm{Hb} \mathrm{H}$ disease: Represents $\alpha$-thalassemia intermedia

4. Thalassemia major: Results in the severe form .[8]

After meticulous searching we cannot find a published article concern with nocturnal enuresis in patients with thalassemia in hereditary blood disease centers, so we try to focus on this subject.

\section{Patients and methods:-}

396 hemoglobinopathies patients with thalassemia and sickle thalassemia from 5-18 years regestrated at heridetary blood disease center in karbala teaching hospital for children from September 2016 to april 2017 .from which 260 patient diagnosed as thalassemia major on regular blood transfusion every 2-4weeks,57 patient diagnosed as thalassemia intermedia ,79 patient diagnosed with sickle thalassemia syndrome.only 61 patients were conducted in our cross sectional study. Other types of hemoglobinopathies with or without diabetes and other chronic illness like heart failure ,renal failure, diabetes insipidus were excluded from the study.

Detail history from all patients and their parents were taken including onset of voiding control ,,day and/or night wet, history of chronic disease(diabetes mellitus, heart failure ,renal failure ), diuretic drug ingestion ,family history of enuresis. After routine physical examination; specific investigation for enuretic patients including general urine examination ,urine culture and abdominal ultrasound for genitourinary system.

By using SPSS 21(Statistical Package for the Social Sciences 21) the assosciation between different types of thalassemia and enuresis evaluated by $\mathrm{P}$ value (significant when $\mathrm{P}<0.05$ ).

\section{Result:-}

Primary enuresis in 51(83.6\%) of 61 patients, $44(83.0 \%)$ in thalassemia major. Secondary enuresis was $10(16.4 \%)$ of 61 patients, $9(17 \%)$ thalassemia major.as shown in table I:

Table-I:- Primary and secondary enuresis in thalassemic and sickle thalassemia:

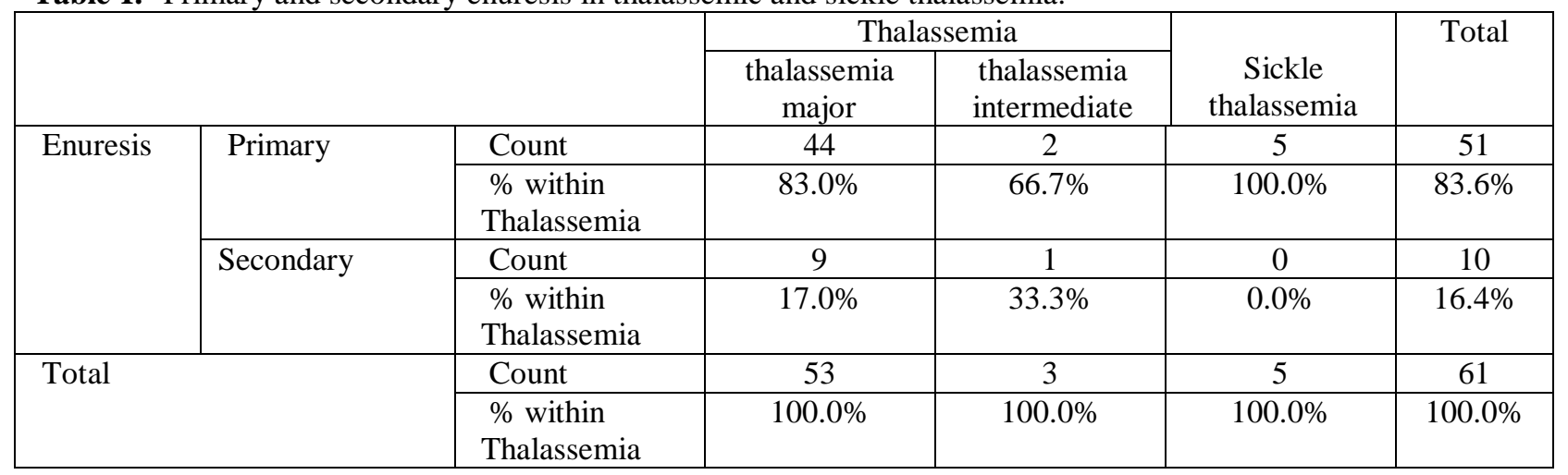


$P$ value 0.4

Males in thalassemia major, thalassemia intermediate and Sickle thalassemia have enuresis were $41(67.2 \%)$ and females were $20(32.8 \%)$ as shown in table II:

Table II:-Gender of enuretic patient with thalassemia and sickle thalassemia

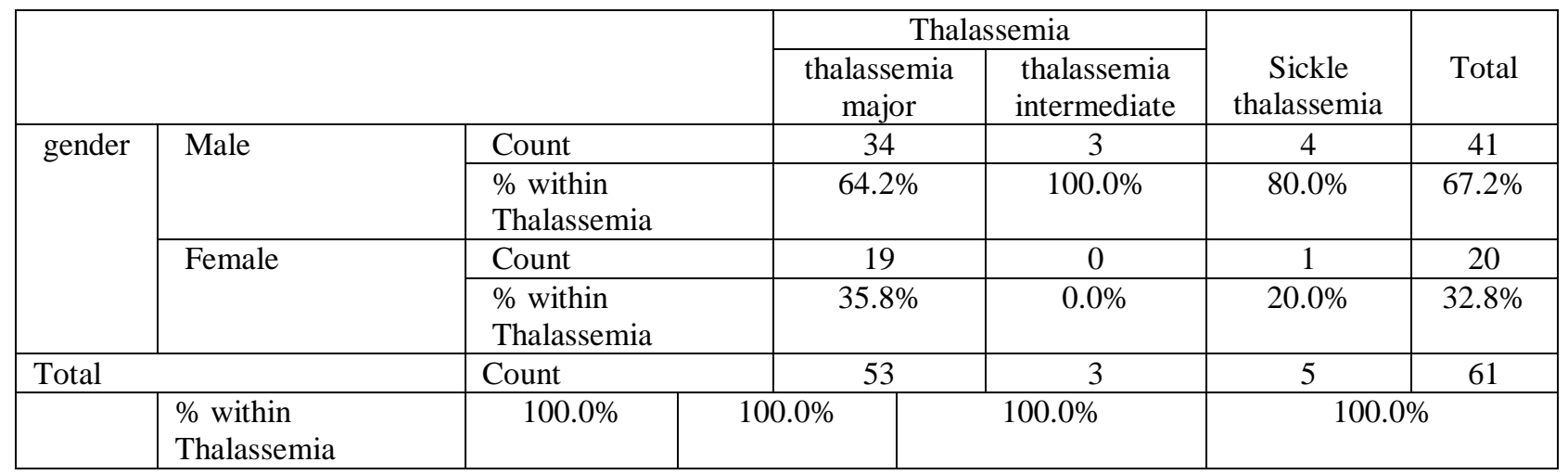

$\mathrm{P}$ value $=0.3$

Family history of enuresis was positive in $46(75.4 \%)$ from 61 thalassemic and sickle thalassemia patients as in table III.

Table-III:-Family history of enuresisin thalassemia and sickle thalassemia:

\begin{tabular}{|c|c|c|c|c|c|c|}
\hline & & & \multicolumn{2}{|c|}{ Thalassemia } & \multirow[b]{2}{*}{$\begin{array}{c}\text { Sickle } \\
\text { thalassemia }\end{array}$} & \multirow[b]{2}{*}{ Total } \\
\hline & & & $\begin{array}{c}\text { thalassemia } \\
\text { major }\end{array}$ & $\begin{array}{l}\text { thalassemia } \\
\text { intermediate }\end{array}$ & & \\
\hline \multirow{4}{*}{$\begin{array}{l}\text { Family } \\
\text { history }\end{array}$} & \multirow[t]{2}{*}{ Positive } & Count & 43 & 1 & 2 & 46 \\
\hline & & $\begin{array}{l}\% \text { within } \\
\text { Thalassemia }\end{array}$ & $81.1 \%$ & $33.3 \%$ & $40.0 \%$ & $75.4 \%$ \\
\hline & \multirow[t]{2}{*}{ Negative } & Count & 10 & 2 & 3 & 15 \\
\hline & & $\begin{array}{l}\text { \% within } \\
\text { Thalassemia }\end{array}$ & $18.9 \%$ & $66.7 \%$ & $60.0 \%$ & $24.6 \%$ \\
\hline \multirow{2}{*}{\multicolumn{2}{|c|}{ Total }} & Count & 53 & 3 & 5 & 61 \\
\hline & & $\begin{array}{l}\% \text { within } \\
\text { Thalassemia }\end{array}$ & $100.0 \%$ & $100.0 \%$ & $100.0 \%$ & $100.0 \%$ \\
\hline
\end{tabular}

$\mathrm{P}$ value $=0.03$

Urinalysis for urinary tract infection in thalassemic and sickle thalassemia patient reveal no significant finding $53(86.9 \%)$ as shown in table IV:

Table-IV:-significant finding for Urinary tract infection in enuretic patients with thalassemic and sickle thalassemia:

\begin{tabular}{|c|c|c|c|c|c|c|}
\hline & & & \multicolumn{2}{|c|}{ Thalassemia } & \multirow[b]{2}{*}{$\begin{array}{c}\text { Sickle } \\
\text { thalassemia }\end{array}$} & \multirow[b]{2}{*}{ Total } \\
\hline & & & $\begin{array}{c}\text { thalassemia } \\
\text { major }\end{array}$ & $\begin{array}{l}\text { thalassemia } \\
\text { intermediate }\end{array}$ & & \\
\hline \multirow[t]{4}{*}{ GUE } & \multirow[t]{2}{*}{ UTI } & Count & 8 & 0 & 0 & 8 \\
\hline & & $\begin{array}{l}\text { \% within } \\
\text { Thalassemia }\end{array}$ & $15.1 \%$ & $0.0 \%$ & $0.0 \%$ & $13.1 \%$ \\
\hline & \multirow[t]{2}{*}{ NoUTI } & Count & 45 & 3 & 5 & 53 \\
\hline & & $\begin{array}{l}\% \text { within } \\
\text { Thalassemia }\end{array}$ & $84.9 \%$ & $100.0 \%$ & $100.0 \%$ & $86.9 \%$ \\
\hline \multirow{2}{*}{\multicolumn{2}{|c|}{ Total }} & Count & 53 & 3 & 5 & 61 \\
\hline & & $\begin{array}{l}\% \text { within } \\
\text { Thalassemia }\end{array}$ & $100.0 \%$ & $100.0 \%$ & $100.0 \%$ & $100.0 \%$ \\
\hline
\end{tabular}


$P$ value $=0.5$

Renal ultrasound was normal in 60(98.4\%) of thalassemic and sickle thalassemia patients, as shown in table V. Table V:-Renal ultrasound findings of thalassemia and sickle thalassemia patients:

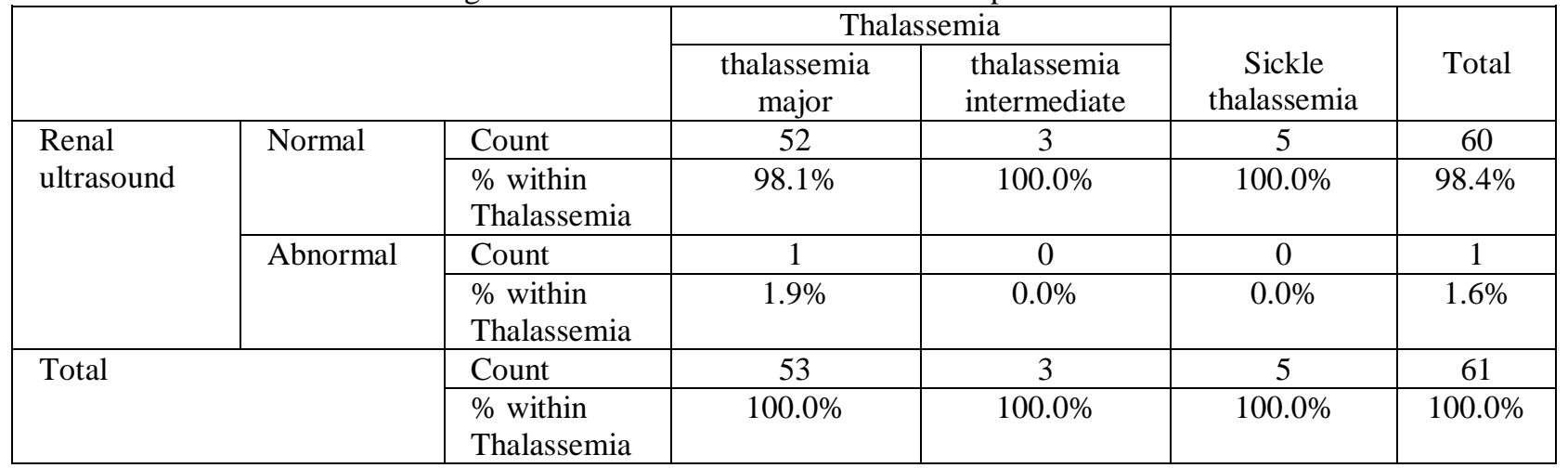

$\mathrm{P}$ value $=0.9$

\section{Discussion:-}

In the current study,the result of Primary enuresis and secondary enuresisin thalassemia major, thalassemia intermediate and Sickle thalassemia were parallel to a cross sectional study performed among children (5-15 years old) visited the general pediatric out patient in Al-Imamain Al-Kadhimain Medical City in the capital Baghdad. In this study the prevalence of nocturnal enuresis was $29.5 \%(\mathrm{n}=184), 84.8 \%(\mathrm{n}=156)$ were of primary type and $15.2 \%$ $(\mathrm{n}=28)$ had secondary nocturnal enuresis [9].

Also this result goes with Robert M. Kliegman, etal,2016 [4].

The result of enuretic males and female patient in thalassemic and sickle thalassemia,was similar to that of Alaa A. Selah, Atheer J. Al-Saffar in Iraqi JMS 2015, in which Males were significantly more enuretic than females $(60.3 \%$ versus $39.7 \%$ and $\mathrm{P}=0.02)[9]$.

Also this result goes with Robert M. Kliegman, et al,2016, which reveals that Approximately $60 \%$ of children with nocturnal enuresis are boys. [4].

In Jamaica (the Caribbean) adopted the prospective interview method recorded a prevalence rate of $45 \%$ among 8 years old sickle cell anemia patients; also noting a male predominance. [10].

The positive Family history of enuresis of thalassemic and sickle thalassemia patients goes with Ekinci $\mathrm{O}$ etal. who Find that family history of nocturnal enuresis and family problems were found to be more frequent in patients with thalassemia major.[11]. And Alaa A. Selah, Atheer J. Al-Saffar in Iraqi JMS 2015, in which positive family history of nocturnal enuresis (including both parents side and siblings), were significantly higher among enuretic children compared to non enuretic children[9].

Our result differs from that of Robert M. Kliegman, et al,2016which states that the Family history is positive in 50\% of cases in general population. [4].

Urinalysis to evaluate urinary tract infection in thalassemic and sickle thalassemia patient reveal no significant finding and this not goes with Alaa A. Selah, Atheer J. Al-Saffar in Iraqi JMS 2015, and Mabiala Babela JR., etal.were children with positive history of urinary tract infection were significant. [9],[11].

However, this may be due to non-exclusion of confounding variables like diabetes mellitus, epilepsy and urinary tract infection these studies. 
Renal ultrasound finding of thalassemic and sickle thalassemic patients seen in one patient $(1.6 \%)(\mathrm{P}$ value $=0.9)$ WhileKovacevic L., etal. Study shows $12.54 \%$ of enuretic children and $5.38 \%$ of controls have abnormal finding $(p=0.004)$, the majority of these findings were clinically insignificant. [13].

\section{Recommendation:-}

1. Thalassemic patients need evaluation of their psychosocial problems.

2. The health care provider in hereditary disease center should be focusing on enuresis as an additional psychosocial burdenon thalassemic patients and their family.

3. We need multidisplinary team for management of enuresis in hereditary blood disease center.

4. We hope to carry out Further studies regarding the incidence and prevalence of enuresis in thalassemic patients.

\section{Reference:-}

1. Fred F. Ferri,M.D.,Ferri clinical advisor five books in one 2016.,Philadelphia,PA 19103-2899.,ISBN:978-0323-28047-1.,PTG Enuresis P:471.

2. http://ayurvedamagazine.org/how-to-stop-bedwetting-in-children/. It is a snapshot of the page as it appeared on 20 Jan 2018 06:20:31 GMT.

3. Yousefichaijan, P., Khosrobeigi, A., Salehi, B., Taherahmadi, H., Shariatmadari, F., Ghandi, Y., ... Farhadiruzbahani, F. (2016). Incidence of obsessive-compulsive disorder in children with nonmonosymptomatic primary nocturnal enuresis. Journal of Pediatric Neurosciences, 11(3), 197-199. http://doi.org/10.4103/1817-1745.193371

4. Robert M. Kliegman, Bonita Stanton, Joseph W. St. Geme, Nina Felice Schor, Richard E. Behrman, Nelson Textbook of Pediatrics, Volume 2, Chapter 543.Enuresis and Voiding Dysfunction page 2585.

5. Hardison RC, Chui DH, Riemer C, et al. Databases of human hemoglobin variants and other resources at the globin gene server. Hemoglobin 2001; 25:183.

6. Ahmed AL Salem,medical and surgical complication of sickle cell anemia,ISBN 978-3-319-24760-1, DOI 10.1007/978-3-319-24762-5,Spriner International Publishing Switzerland 2016,page 51.

7. Colah R, Gorakshakar A, Nadkarni A. Global burden, distribution and prevention of $\beta$-thalassemias and hemoglobin E disorders. Expert review of hematology. 2010 Feb 1;3(1):103-17.

8. Hassan M Yaish, MD; Pediatric Thalassemia, Medscape, Updated: Aug 23, 2017., https://emedicine.medscape.com/article/958850-overview

9. Alaa A. Saleh1 MBChB, Atheer J. Al-Saffar2 MBChB, FICMS Nocturnal Enuresis and its Relation to Child's Behavior in a Sampleof Children from Baghdad, Iraq Iraqi JMS 2015; Vol.13(1) p:9

10. Uwaezuoke, Samuel. (2016). Nocturnal enuresis in children with sickle-cell anemia: global prevalence rates, gender bias and hypotheses on pathogenesis. Internal Medicine Review... 10.18103/imr. v0i5.119.

11. Ekinci $\mathrm{O}^{1}, \underline{\text { Celik T }}$, Ünal Ș, Oktay G, Toros F, Ozer C Nocturnal enuresis in sickle cell disease and thalassemia major: associated factors in a clinical sample Int. J. Hematol. 2013 Oct;98(4):430-6. doi: 10.1007/s12185-0131422-9. Epub 2013 Sep 8

12. Mabiala Babela JR, Loumingou R, Pemba-Loufoua A, Nzingoula S, Senga P. Enuresis in children with sickle cell disease. Arch Pediatr. 2004; 11(10):1168-1172. PMID: 15475271)\}, \{(Akinyanju O, Agbato O, Ogunmekan AO, Okoye JU. Enuresis in sickle cell disease. I. Prevalence studies. J Trop Pediatr 1989; 35(1):2426. doi: 10.1093/tropej/35.1.24

13. Kovacevic L, Wolfe-Christensen C, Mirkovic J, Yih J, Lakshmanan Y Renal bladder ultrasound evaluation in monosymptomatic primary nocturnal enuresis: is it really necessary? 2014 Jul;29(7):1189-94. doi: 10.1007/s00467-013-2742-y. Epub 2014 Jan 18. 